Reflection

ISSN: 2162-3104 Print/ ISSN: 2166-3750 Online

Volume 7, Issue 3 (2017), pp. 918-924

(c) Journal of International Students

http://jistudents.org/

doi: 10.5281/zenodo.570041

\title{
Logging On: Using Online Learning to Support the Academic Nomad
}

\author{
Terra Gargano \\ Julia Throop \\ American University, USA
}

\begin{abstract}
The Internet is cited for bringing about the most rapid and significant social change within societies worldwide. Higher education does not lie at the fringe of this discussion, but is rather at the center of it. Online learning is no longer considered a mere supplement to education but digital tools now routinely embed themselves in higher education spaces. The evolving modalities of online learning are expanding the terrain of academic possibilities farther than previously imagined and new educational technologies are introduced daily. Against a backdrop of the potential for online learning in higher education, this article will paint a portrait of the ways one graduate program at a United States institution of higher education is addressing demands of academic nomads.
\end{abstract}

Keywords: academic nomad, online learning, international higher education, mobility

If some form of online education, which is simply a continuation of the myriad forms of distance education, has been around for over half a century, why is everyone suddenly talking about it now? Each year from 2004-2013, enrollment in online learning grew a record $2 \%$ over the previous year. By 2014, close to a third of all higher-education enrollments in the U.S. were online, with almost 7 million students enrolled in at least one online class (Allen, Seaman, Poulin, \& Straut, 2016). Online education has gone from being at the margin of the discourse to the very center of it and is gaining mainstream acceptance. From renowned universities to educational startups, from publishing houses to software companies, industry leaders realize the potential of online education to democratize and revolutionize global education. 
Likewise, the international education industry today is gaining recognition for the number and variety of functions it performs: the ability to drive political initiatives, spur economic gains, and support opportunities for transnational collaboration and cultural diplomacy. The authors addresses how the marriage of these two burgeoning industries, international education and technological innovation, can tackle common global challenges in higher education and create spaces that expand the terrains of possibilities for academic nomads.

\section{ONLINE AND BLENDED LEARNING}

The phrase "online learning" may be new, but what it defines is not new. Rapid advances in technological innovation are creating new spaces for student engagement and collaboration that possess the potential to generate unprecedented authentic learning experiences and partnerships. The world of online learning is multifarious and contains multiple competing definitions and conceptualizations. Online and blended learning is defined and characterized by:

“...its ability to facilitate a community of inquiry. Community provides the stabilizing, cohesive influence that balances the open communication and limitless access to information on the Internet. Communities also provide the condition for free and open dialogue, critical debate, negotiation and agreement-the hallmark of higher education. Blended learning has the capabilities to facilitate these conditions and adds an important reflective element with multiple forms of communication to meet specific learning requirements" (Garrison 2004, p. 97).

Online education is characterized by the terrain of possibilities it presents to learners. Coupled with the statistics on worldwide Internet usage, the authors posit that online education, with its ability to expand access and to accommodate high demand, is well-positioned to be applied to the international education industry to successfully correct some of higher education's top global challenges and meet the needs of changing student demographics and a new kind of student, the academic nomad.

\section{ACADEMIC NOMAD}

Parent, bilingual, veteran, part-time student, online student, scholarship awardee, international student, dual citizen, traveling professional: how frequently do you come across a student who is only one of these things? Fewer and fewer students are members of only one single category. Instead, students are living their lives at the juncture of identities, often creating their own salient "selves" that better represent the intersectionality of their lives. 
Exchanging binary identities for a new term, the "academic nomad," not only liberates those in higher education from making generalizations, but also helps to paint a more complete picture of the evolving student demographic. The academic nomad is a student without a demographic home or category; who is simultaneously a member of and alien to any one specific category. The academic nomad is a term that serves a dual purpose: (a) it forces diversity of thought and perspective in the international education quorum, and (b) it forces institutions to acknowledge the plurality of student identities and to become responsive to the elasticity of student profiles and needs.

Figure 1: America in 100 Students

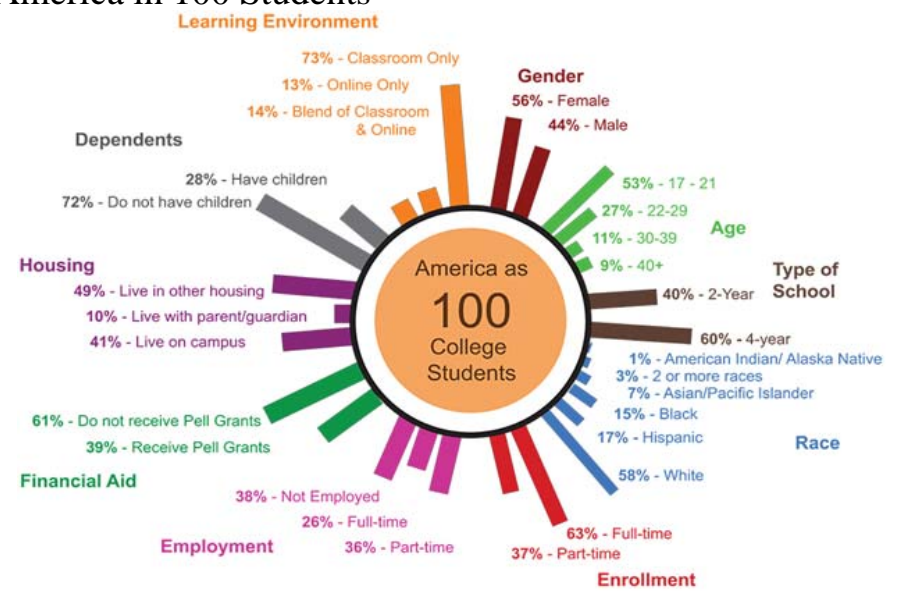

Graphic designed by Chris Zeigler, DC Social Media Strategies, LLC

Data from The Gates Foundation

The graph above illustrates the increasing diversity of graduate students at U.S. colleges and universities. Compounded by frequent overseas posts and relocations due to professional obligations, the resulting graduate student experience is one not grounded in a geographic location, but one grounded in mobility. The term "international student" denotes someone who comes from a country outside of the host country to study. But what term describes a student who completes a graduate degree from fifteen different countries throughout their degree program?

The term academic nomad captures the mobility and fluidity of students in this increasingly blended learning environment and offers an inclusive approach to visualizing mobility in the lives of all students as they shape and reconfigure their academic pathways. It is through a reconceptualization of conventional terms and definitions that higher education institutions can adapt to new demographics, technologies, and possibilities. 


\section{Academic Nomads at One Institution}

As institutions struggle to meet growing demands, as the costs of attendance are negotiated, as regional conflicts continue to flare, and as the global workforce travels across many borders, the integrity of online education prevails. The online MA in International Relations (MAIR) at American University's School of International Service is one program that addresses the lives and challenges experienced by academic nomads.

The graduate students in the MAIR online program currently total approximately 275, making it the largest graduate program in the School of International Service. Ninety-five percent of these students report working full time, $24 \%$ report that they are first-generation college students, and the median age of students scales slightly higher than on-campus students. Forty percent of the student body claims affiliation with the military. The majority of graduate students in the program frequently travel for work, covering fourteen different time zones, with one student completing her degree from nine different countries. The mobility in the lives of these students is not unique. Online education allows these academic nomads to access an education that travel, family responsibilities, or professional duties would otherwise prevent.

There is no "typical student" in the MAIR online program, but some students come to the forefront as examples of their generation. Sichao $\mathrm{Ni}$ is a first-generation college student who moved to the United States from China at eight years old. While completing his Bachelor degree, Sichao studied abroad and completed internships in six different countries. While enrolled in the MAIR online program, he further expanded his international horizons by participating in a short-term study abroad program in South Africa.

"We learned from leading scholars and discussed a variety of issues concerning South Africa, including foreign policy, inequality, education, HIV/AIDS, economic and political history, domestic politics, environment sustainability and much more. During the second week, we traveled to villages, went to the office of the opposition party, visited NGOs, schools and learning centers, and the Chamber of Commerce to see and listen to how the issues studied in classroom come to play in real life and real world policies. I think the opportunity for a MAIR online student to participate in on-campus experiences and participate in study abroad opportunities is highly valuable. This was a significant factor in my decision to participate. I see this as an investment that will generate many fruitful returns down the road as I apply for job opportunities” (Ni, 2016). 
Like many students in the program, Sichao saw the program as not only offering him a virtual space but a variety of ways to multiply his dimensions of educational interaction. The online learning experience is rarely restricted to virtual spaces. The MAIR online program also requires on-campus components. While the technology allows students to attend career-focused webinars and virtually network, to conduct research with faculty on campus, to complete weekly asynchronous coursework and participate in weekly synchronous sessions, and to participate in livestreamed campus events, the on-campus Immersion experience gives students an additional way to interact with their program.

The MAIR online program boasts a faculty roster of over one hundred content experts. In addition to the United States, these faculty members collectively come from over 15 different countries and collectively speak over 25 different languages. Since its inception, faculty have hosted courses in over a dozen countries, where they are performing research or assessments in the field. These internationally-hosted sessions, in combination with the faculty's talents and skills, give students a true window into the practitioner's life. As faculty and students travel, co-presenting on panels or enjoying coffee at local cafes when paths cross, a community of mentors is forming. The opportunity to meet and interact with fellow students, faculty, and staff during this program makes the online format and modality of the program that much more engaging and meaningful.

\section{CONCLUSION}

"The challenges facing education are numerous and varied. There have been attempts, some successful, made to address them in the past. But what makes this period momentous is that technology makes it possible to break into another space and time, taking education to a whole new plane” (Harish, 2013, p.29).

At its best, online and blended learning programs capture the essence of education, yet online learning cannot be complete without immersive and authentic learning. Online education is one point in a long continuum. Since there is no telling what lies ahead, the concepts and definitions need to be stable enough to mature with time. Versatile and diverse blended academic options can help institutions remain relevant amid shifting challenges. The traditional labels used to describe students, either as international students or online students, need to be re-conceptualized to address the mobility and the lived reality of academic nomads today.

Online education provides institutions and educators the opportunity to engage students where they are, ensuring those who want to expand the geography of the mind are able to do so. The MAIR online program was the second such degree done by Kishor Narayan, who completed his first online 
degree in 2008. Kishor, based in Bangalore, India, would wake up at 3:30 am local time to attend synchronous sessions for the MAIR online program before traveling to work. Kishor even attended one live session while waiting in the parking lot of a hospital, where his wife was inside preparing to give birth to their first son. "Bangalore is not an international city. As a student in this program, the quality of education was higher than anything I could have received locally" (Narayan, 2016). Online learning is what allows American University and other institutions of higher education to open up new options for students like Narayan.

Emily Ham is another example of an academic nomad. While serving as a lieutenant in the United States Navy, Emily sat through lectures in fifteen countries, attended classes from 9 different time zones, and joined her classmates from trains, planes, and automobiles. At one point, she even submitted an assignment from a ferry boat crossing the English Channel. Emily is the perfect portrait of a dedicated, engaged graduate student. Upon seeing her speak at the commencement ceremony in May 2015, no one would have guessed that was her first-ever visit to American University's campus. While Emily's story might seem unique, it is tied to the nomadic phenomenon described here and is a bellwether for how the educational times are changing. It is not enough to simply teach today's students as we taught yesterday's students. Instead, we must strive to teach all students in the memory of tomorrow.

\section{REFERENCES}

@dan_greenstein. (2016). America as 100 College Students - Bill \& Melinda Gates Foundation - Postsecondary Success. Retrieved from http://postsecondary.gatesfoundation.org/areas-of-focus/incentives/policyadvocacy/advocacy-priorities/america-100-college-students/

Allen, I. E., Seaman, J., Poulin, R., \& Straut, T. T. (2016, February). Online report card: Tracking online education in the United States. Babson Survey Research Group.

Garrison, D., \& Kanuka, H. (2004, February). Blended learning: Uncovering its transformative potential in higher education. Internet and Higher Education, 7, 95-105.

Ham, E. (2015, May 10). Graduate commencement speech. Speech presented at American University, Washington DC.

Harish, J. (2013, October). Online Education: A Revolution in the Making. CADMUS: Promoting Leadership in Thought That Leads to Action, 2(1), 26-38.

Narayan, K. (2016, May 07). Personal interview.

Ni, S. (2016, August 28). Personal interview.

Open Doors Report. (2016). Retrieved from http://www.iie.org/Research-andPublications/Open-Doors. 
TERRA GARGANO holds a Ph.D. in International Education Policy from the University of Maryland, and completed her Master's degree at American University. Terra serves as the faculty advisor for Online Programs in the School of International Service and teaches undergraduate and graduate courses in intercultural and cross-cultural communication, training in online contexts, and qualitative research methods both online and on campus. She spent time teaching English in Japan and was the Assistant Dean of Semester at Sea for the Institute for Shipboard Education before serving as a faculty member at American University as well as the University of Maryland. Throughout her career in international education, she has managed dozens of study abroad programs and institutional collaborations worldwide. Email: gargano@american.edu.

JULIA THROOP is a graduate of American University's School of International Service MA in International Communication program. Julia's research focuses on the intersection of online/distance learning and global higher education. In her professional role, Julia serves as Advisement Specialist to graduate students in American University's International Relations Online degree program. Email: jthroop@american.edu. 